Article

\title{
Modulatory Effects of Interspecific and Gourd Rootstocks on Crop Performance, Physicochemical Quality, Bioactive Components and Postharvest Performance of Diploid and Triploid Watermelon Scions
}

\author{
Marios C. Kyriacou ${ }^{1, *(D)}$, Georgios A. Soteriou ${ }^{1(D)}$ and Youssef Rouphael ${ }^{2}(\mathbb{D}$ \\ 1 Department of Vegetable Crops, Agricultural Research Institute, Nicosia 1516, Cyprus; soteriou@ari.gov.cy \\ 2 Department of Agricultural Sciences, University of Naples Federico II, 80055 Portici, Italy; \\ youssef.rouphael@unina.it \\ * Correspondence: m.kyriacou@ari.gov.cy; Tel.: +357-2240-3221
}

Received: 28 July 2020; Accepted: 14 September 2020; Published: 15 September 2020

check for updates

\begin{abstract}
Vegetable grafting has become entrenched as a sustainable tool for addressing biotic and abiotic stresses of vegetable crops, including watermelon. The concerted action of scion-rootstock genotypes in shaping crop performance, fruit quality and postharvest behavior of watermelon is critical. In this respect, scions of different ploidy grafted on interspecific and gourd rootstocks were assessed. Yield traits were strongly influenced by rootstock, as opposed to fruit morphometric characteristics. Interspecific rootstock supported stable yield across seasons with a $20.5 \%$ increase over gourd, and induced thicker rind and higher pulp firmness by $30.1 \%$ over gourd, which constitute advantageous traits for shelf-life. Interspecific rootstock also increased lycopene content, which was further influenced by scion genotype irrespective of ploidy. Triploid cultivars attained higher firmness but lower sugars than diploid, which renders the former particularly prone to loss of sensory quality during postharvest depletion of sugars. Although total and reducing sugars decreased during storage, sucrose increased, which in conjunction with the postharvest accumulation of lycopene sheds new light on the postharvest physiology of watermelon. The marginal rootstock effect on sugars renders interspecific rootstock superior to gourd on account of higher yield, firmness and lycopene content. The present work constitutes a contribution toward understanding rootstock-scion relations and how they mediate crop performance, fruit quality and postharvest behavior of watermelon.
\end{abstract}

Keywords: Citrullus lanatus (Thunb) Matsum and Nakai; functional quality; lycopene; storage; sugars; texture

\section{Introduction}

Grafting has become globally entrenched as an imperative and sustainable tool for overcoming biotic and abiotic stresses confronting vegetable crops [1]. Watermelon (Citrullus lanatus (Thunb) Matsum and Nakai) in particular is the crop that has known the widest application of grafting onto rootstocks resistant to soilborne pathogens or resilient to salinity, water stress, nutrient stress, heat stress, organic pollutants, alkalinity, acidity and contamination of soils by heavy metals [2-4]. Grafting may thus facilitate cultivation of watermelon and other vegetable fruit crops in previously non-arable land and contribute toward global food security. Notwithstanding the importance of grafting for managing biotic and abiotic stress conditions, fruit quality and composition is also modulated by scion-rootstock interaction although it has received comparatively far less attention than the phytoprotection and 
physiology aspects of crop production [5]. The potential of exploiting wild genetic resources for stress-tolerant rootstocks compatible to commercial scions can be a faster route to trait stacking than breeding; moreover, it may bypass undesirable pleiotropic effects on fruit quality traits that befall breeding based on selection of desirable qualitative traits [6]. Toward this end, analytical information is essential on how rootstock-scion interaction under field conditions may impact physical, chemical, bioactive and sensory components of fruit quality. In this respect, it is important to examine how different scion types (e.g., diploid vs. triploid or mini vs. large fruited) may interact with different rootstock types (e.g., interspecific vs. gourd) to configure crop performance and fruit quality.

Changes in fruit physicochemical composition and morphometric characteristics also inevitably bear an impact on the postharvest performance of watermelon, which has received little attention to date [1,7]. Yet fruit quality along the horticultural supply chain and ultimately at the customer end is largely influenced by postharvest handling and storage practices. Watermelon is a non-climacteric fruit with a cultivar-dependent but overall brief shelf-life of less than three weeks at $10-15^{\circ} \mathrm{C}$ [8]. Previous work on rootstock-mediated watermelon postharvest performance is limited, but has established that grafting effects on the physicochemical composition of watermelon fruit extend to the postharvest period [1,9]. It is therefore critical to understand how different rootstock types may interact with different scion types to configure postharvest changes in sensory, compositional and functional quality traits that ultimately define shelf-life.

Accordingly, the current work examined how rootstocks TZ148 and Festival, which represent the two major classes of exploited rootstocks-interspecific hybrids (Cucurbita maxima (Duchesne) $\times$ C. moschata (Duchesne ex Poir)) and gourd (Lagenaria siceraria L.), respectively-interacted with two mini triploid (Extazy and Petite), two mini diploid (Vivlos and Esmeralda) and one large-fruited diploid scion cultivar (Pegasus) to impact crop performance and fruit morphometric characteristics. Moreover, fruit sensory quality traits (pulp colorimetry, firmness, sweetness index), chemical composition (fructose, glucose, sucrose) and bioactive components (lycopene and citrulline) were examined at harvest and following postharvest storage at $25^{\circ} \mathrm{C}$ for 10 days. The current work constitutes a contribution toward understanding rootstock-scion relations and how they mediate crop performance, fruit quality and postharvest behavior of watermelon.

\section{Materials and Methods}

\subsection{Location and Plant Material}

The study was carried out for two successive years (2018-2019) between April and July, at the Tohni Experimental Station $\left(34^{\circ} 44^{\prime} 00^{\prime \prime} \mathrm{N} ; 33^{\circ} 20^{\prime} 15^{\prime \prime}\right.$ E) of the Agricultural Research Institute of Cyprus. The area has a typical Mediterranean climate with rainfall occurring mainly between November and March. During the study, average day-time temperature ranged from 29 to $40{ }^{\circ} \mathrm{C}$. Transplants of two mini (3-5 kg) diploid cultivars (Esmeralda and Vivlos), two mini triploid cultivars (Extazy and Petite) and a large-fruited (8-12 kg) diploid cultivar (Pegasus) were grafted onto C. maxima $\times$ C. moschata (TZ148) and Lagenaria siceraria (Festival) rootstocks. Grafts were made by approach grafting as described previously by Soteriou and Kyriacou [10]. All transplants were produced at a commercial nursery. Planting was performed in late April, on an alkaline ( $\mathrm{pH}$ 7.5) clay-loam soil at a plant density of approximately 3333 plants ha ${ }^{-1}$ with $1.0 \mathrm{~m}$ spacing on the row and $3.0 \mathrm{~m}$ between rows. An amount of $350 \mathrm{~kg} \mathrm{ha}^{-1}$ of compound fertilizer $14 \mathrm{~N}-9.6 \mathrm{P}-7.5 \mathrm{~K}$ was applied into the soil

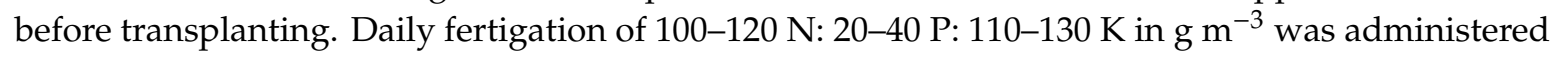
through the drip irrigation beginning ten days after transplanting; the higher rates were provided with flowering initiation. Daily inspection and flower tagging at anthesis (fruit setting) secured uniformity in fruit harvest maturity [11]. Applied pest and disease control practices were standard for the region. The postharvest period spanned 10 days of storage in a refrigerated chamber equipped with a Carel, UE001PD000 humidifying system (Carel Industries S.p.A., Brugine PD, Italy) held at $25 \pm 0.5^{\circ} \mathrm{C}$ and $90 \%$ relative humidity. 


\subsection{Measurements and Analyses}

Fruits were weighed and equatorial and meridian diameters were determined with a Vernier caliper at harvest. Yield and number of fruits per hectare were estimated. All underdeveloped fruit were considered unmarketable. Cross-sections of marketable fruit typical for each of the five scion cultivars are presented in Figure 1. Quality assessment was performed by sampling randomly three fruit from each plot. All sampled fruit for quality assessment purposes had been set on the same calendar date \pm 1 day and harvested simultaneously $40 \pm 1$ days later. An electronic caliper was used at two representative points on each cross-sectioned fruit for assessing fruit rind. Watermelon flesh firmness was recorded by a TA.XT plus Texture Analyser (Stable Micro Systems, Surrey, UK) as described previously [11]. The Texture Analyser protocol was set to measure flesh firmness as the maximum resistance force to penetration to a depth of $50 \mathrm{~mm}$ around the heart of each cross-sectioned fruit. A Minolta CR-400 Chroma Meter (Minolta, Osaka, Japan) was used to assess flesh color at two loci in the heart region of each fruit in cross section using the CIELAB color space to record lightness $\left(L^{*}\right)$, chroma coordinates $a^{*}$ and $b^{*}$, chroma $\left(C^{*}\right)$, and hue angle $\left(h^{\circ}\right)$ [12]. A homogenate was obtained from the excised heart of each fruit using a Vita Prep 3 (Vita-Mix Corp., Cleveland, OH, USA) blender under low speed to prevent foaming. Using a digital refractometer (RFM870; Bellingham-Stanley Ltd., Kent, UK), part of the homogenate was used, after double cheesecloth filtration, for determining juice total soluble solids content (TSS) at $20^{\circ} \mathrm{C}$. A pH electrode (SevenMulti, Mettler-Toledo GmbH, Schwerzenbach, Switzerland) was used for measuring the $\mathrm{pH}$ of the juice. Falcon tubes $(50 \mathrm{~mL})$, instantly dip-frozen in liquid nitrogen, were used to store part of the homogenate at $-80^{\circ} \mathrm{C}$ for further chemical analyses.

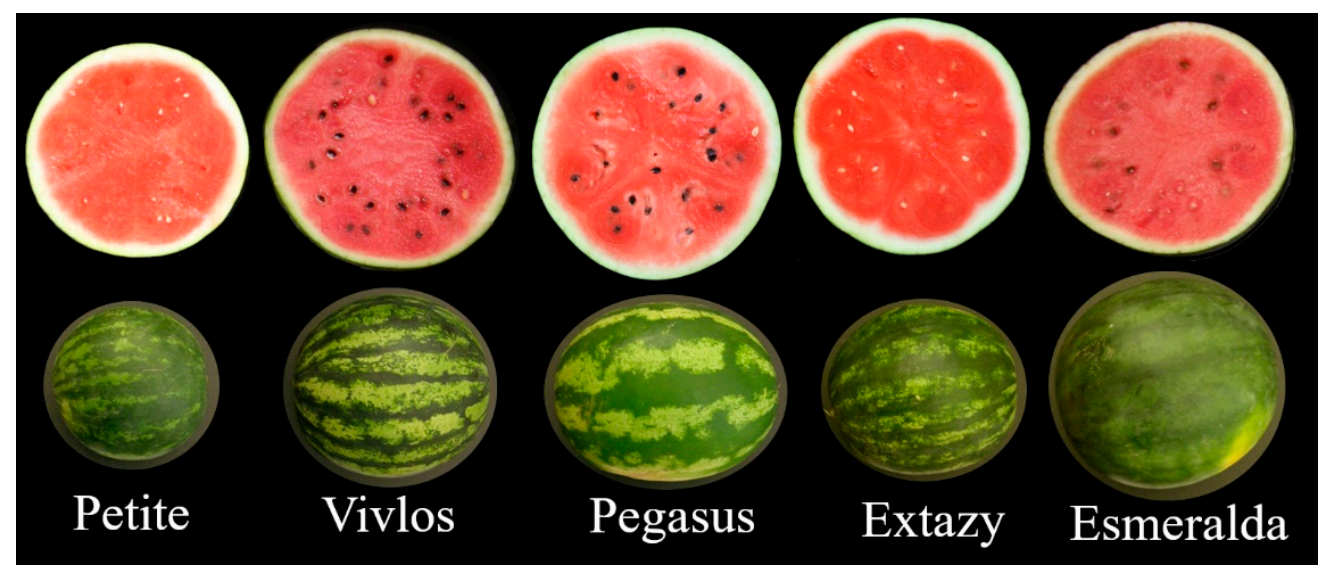

Figure 1. Intact and cross-sectioned watermelon fruit of cvs. Petite, Vivlos, Pegasus, Extazy and Esmeralda.

Lycopene extracted in hexane was determined according to the method of Perkins-Veazie et al. [13]. Lycopene was quantitated against pure hexane on a Jasco V-550 UV-VIS spectrophotometer (Jasco Corp., Tokyo, Japan) at $503 \mathrm{~nm}$ using the extinction coefficient of $17.2 \times 104 \mathrm{M}^{-1} \mathrm{~cm}^{-1}$. Non-structural carbohydrates (glucose, fructose, sucrose) were analyzed by liquid chromatography on an Agilent HPLC system (Agilent Technologies, Santa Clara, CA, USA) equipped with a 1200 Series quaternary pump and a 1260 Series refractive index detector using a $4.6 \times 250 \mathrm{~mm}$ carbohydrate column at $35{ }^{\circ} \mathrm{C}$ (Waters, Milford, MA, USA) and acetonitrile:water (75:25) as mobile phase at $1.4 \mathrm{~mL} \mathrm{~min}^{-1}$ for separation (detailed description provided in Kyriacou et al. [1]). Quantification was performed against external standard calibrating curves with a coefficients of determination $\left(R^{2}\right)>0.9999$. Citrulline was also analyzed on the same HPLC system equipped with an Agilent 1260 Series PDA detector using the method of [1]. 


\subsection{Experimental Design and Statistical Analysis}

The study included two experiments. The first experiment was designed as a factorial two-way completely randomized design, with five cultivars ('Petite', 'Vivlos', 'Pegasus', 'Extazy', 'Esmeralda') and two graft combinations ('TZ148', 'Festival'). In the second experiment, post-harvest storage was also included as a third factor in a factorial three-way completely randomized design. In both experiments, each field plot was replicated 4 times and consisted of 5 plants. Each year was analyzed separately. Data were subjected to analysis of variance (ANOVA) using SAS (SAS Institute, Inc., Cary, NC, USA). Means were separated with the Tukey-Kramer HSD test, provided absence of significant cultivar-by-rootstock interaction.

\section{Results}

\subsection{Crop Performance Characteristics}

Crop performance characteristics such as tradable yield, number of fruits and fruit weight were influenced by both scion and rootstock, whereas variation in fruit shape was dictated strictly by the scion genotype in both years of experimentation (Table 1). The relative effects of scion cultivar and rootstock on all yield characteristics varied between years, with rootstock rendered less influential in the second year. Rootstock effect was most pronounced on tradable yield whereas fruit number, fruit weight and fruit shape were influenced overwhelmingly by cultivar. Cultivar $\times$ rootstock interaction was non-significant for all yield characteristics as scion and rootstock ranking remained unaltered between years. Tradable yield was highest in the large-fruited diploid Pegasus, which did not differ significantly, however, from that of the mini triploid cultivars Petite and Extazy. Yield was notably low in the diploid cultivar Vivlos, which was lower than the average yield of the mini triploid cultivars by $37 \%$ and $38 \%$ in the first and second year, respectively. Fruit weight was lowest for Extazy $(3.2 \pm 0.2 \mathrm{~kg})$ but invariable $(4.2-4.4 \mathrm{~kg})$ across the rest of the mini scions. Inversely, the highest number of fruits per hectare was obtained from Extazy and the lowest from the large-fruited Pegasus. Low fruit weight combined with low number of fruits, tantamount to low yield, was evidenced only in Vivlos. The choice of rootstock had a consistent effect in both years on yield, number of fruits per hectare and fruit weight, which were in all cases higher with TZ148 than Festival. 
Table 1. Mean comparison for yield, fruit number, fruit mean weight, fruit shape (meridian/equatorial diameter), at harvest of watermelon fruit from cvs. Petite,

Vivlos, Pegasus, Extazy and Esmeralda grafted on two rootstocks types. Values represent means \pm SE.

\begin{tabular}{|c|c|c|c|c|c|c|c|c|c|c|c|c|c|c|c|c|c|}
\hline \multirow{3}{*}{ Source of Variance } & \multirow[b]{3}{*}{ DF } & \multicolumn{4}{|c|}{ Yield } & \multicolumn{4}{|c|}{ Fruit Number } & \multicolumn{4}{|c|}{ Fruit Weight } & \multicolumn{4}{|c|}{ Fruit Shape } \\
\hline & & \multicolumn{4}{|c|}{$\left(\mathrm{tha}^{-1}\right)$} & \multicolumn{3}{|c|}{ (fruits ha ${ }^{-1}$ ) } & & \multicolumn{4}{|c|}{ (kg) } & \multicolumn{4}{|c|}{$(\mathrm{M} / \mathrm{E})$} \\
\hline & & \multicolumn{2}{|l|}{ Year 1} & \multicolumn{2}{|l|}{ Year 2} & \multicolumn{2}{|l|}{ Year 1} & \multicolumn{2}{|l|}{ Year 2} & \multicolumn{2}{|l|}{ Year 1} & \multicolumn{2}{|l|}{ Year 2} & \multicolumn{2}{|l|}{ Year 1} & \multicolumn{2}{|l|}{ Year 2} \\
\hline & \multicolumn{17}{|c|}{ ANOVA-Mean Squares } \\
\hline Cultivar (C) & 4 & 1388.9 & $* * *$ & 1652.234 & $* * *$ & 182311321.5 & $* * *$ & 224157607.8 & $* * *$ & 25.7 & $* * *$ & 42.9 & $* * *$ & 0.058 & $* * *$ & 0.062171 & $* * *$ \\
\hline Rootstock (R) & 1 & 3273.6 & $* * *$ & 456.9798 & $* *$ & 30303846 & $*$ & 15715838 & $*$ & 4.5 & $* * *$ & 0.02 & & $9 \times 10^{-4}$ & & $2 \times 10^{-5}$ & \\
\hline $\mathrm{C} \times \mathrm{R}$ & 4 & 108.10 & & 371.0818 & & 8201830.5 & & 11371952 & & 0.2 & & 0.13 & & $1 \times 10^{-4}$ & & $5 \times 10^{-4}$ & \\
\hline Cultivar & & \multicolumn{16}{|c|}{ Mean Comparisons } \\
\hline Petite & & $73.5 \pm 3.7$ & a & $93.8 \pm 3.7$ & $\mathrm{a}$ & $16704 \pm 854$ & $\mathrm{~b}$ & $17920 \pm 854$ & $\mathrm{~b}$ & $4.4 \pm 0.2$ & $\mathrm{~b}$ & $5.2 \pm 0.2$ & $\mathrm{~b}$ & $1.04 \pm 0$ & $\mathrm{~b}$ & $1.03 \pm 0$ & $\mathrm{~b}$ \\
\hline Vivlos & & $45.2 \pm 3.7$ & c & $55.1 \pm 3.7$ & c & $10752 \pm 768$ & $\mathrm{~cd}$ & $12096 \pm 768$ & c & $4.2 \pm 0.1$ & $\mathrm{~b}$ & $4.6 \pm 0.1$ & $\mathrm{~b}$ & $1.04 \pm 0.01$ & $\mathrm{~b}$ & $1.04 \pm 0.01$ & $\mathrm{~b}$ \\
\hline Pegasus & & $78.6 \pm 4.1$ & $\mathrm{a}$ & $96.3 \pm 4.1$ & $\mathrm{a}$ & $9984 \pm 555$ & $\mathrm{~d}$ & $10950 \pm 555$ & d & $7.9 \pm 0.2$ & a & $8.8 \pm 0.2$ & a & $1.23 \pm 0.01$ & $\mathrm{a}$ & $1.24 \pm 0.01$ & $\mathrm{a}$ \\
\hline Extazy & & $69.2 \pm 5.7$ & $\mathrm{ab}$ & $82.4 \pm 5.7$ & $a b$ & $21632 \pm 1260$ & $\mathrm{a}$ & $22058 \pm 1260$ & $\mathrm{a}$ & $3.2 \pm 0.2$ & c & $3.7 \pm 0.2$ & c & $1.04 \pm 0.01$ & $\mathrm{~b}$ & $1.04 \pm 0.01$ & $\mathrm{~b}$ \\
\hline Esmeralda & & $59.7 \pm 5.2$ & $\mathrm{~b}$ & $72.6 \pm 5.2$ & $\mathrm{~b}$ & $13504 \pm 912$ & $\mathrm{bc}$ & $15793 \pm 912$ & $\mathrm{~b}$ & $4.4 \pm 0.3$ & $\mathrm{~b}$ & $4.6 \pm 0.3$ & $\mathrm{~b}$ & $1.06 \pm 0$ & $\mathrm{~b}$ & $1.07 \pm 0$ & $\mathrm{~b}$ \\
\hline \multicolumn{18}{|l|}{ Rootstock } \\
\hline TZ148 & & $74.3 \pm 3.4$ & $\mathrm{a}$ & $83.4 \pm 3.4$ & a & $15385 \pm 1130$ & a & $16394 \pm 1130$ & $\mathrm{a}$ & $5.2 \pm 0.4$ & a & $5.5 \pm 0.4$ & & $1.1 \pm 0.01$ & & $1.1 \pm 0.02$ & \\
\hline Festival & & $56.2 \pm 3.1$ & $\mathrm{~b}$ & $76.6 \pm 3.1$ & $\mathrm{~b}$ & $13644 \pm 1076$ & $\mathrm{~b}$ & $15132 \pm 1076$ & $\mathrm{~b}$ & $4.5 \pm 0.4$ & $\mathrm{~b}$ & $5.3 \pm 0.4$ & & $1.1 \pm 0.01$ & & $1.1 \pm 0.02$ & \\
\hline
\end{tabular}

$\mathrm{DF}=$ degrees of freedom. ${ }^{*}$ Significant effect at the 0.05 level, ${ }^{* *} 0.01$ level, ${ }^{* * *} 0.001$ level. Means within each column followed by different letters denote significant differences $(p<0.05)$ according to the Tukey-Kramer HSD test. 


\subsection{Physical Quality Characteristics of Watermelon Fruit}

Physical quality characteristics of watermelon fruit, such as rind thickness, pulp firmness and pulp color, were predominantly determined by the scion cultivar, which accounted for most of the variance observed in these traits (Table 2). Rootstock effect was most pronounced on pulp firmness whereas storage had its greatest effect on rind thickness and the colorimetric values of the pulp. In both years, the thickest watermelon rind was found in the mini triploid cultivar Extazy and the thinnest in the mini diploid Vivlos. Rootstock had a significant effect on rind thickness only in the first year of experimentation whence the interspecific rootstock TZ148 induced a thicker rind than the Lagenaria rootstock Festival. Pulp firmness was highest in the triploid mini cultivars Extazy and Petite and lowest in the diploid cultivars. Rootstock had a significant effect on firmness with TZ148 imparting higher firmness than Festival by $28.9 \%$ and $31.3 \%$ in the first and second year, respectively. The effect of storage on firmness was marginally significant in both years with mean firmness reduced after 10-day storage at $25{ }^{\circ} \mathrm{C}$ by merely $8.0 \%$ and $5.5 \%$ in the first and second year, respectively. The colorimetric variables of the pulp were influenced mainly by scion cultivar and less so by rootstock and storage. Lightness $\left(\mathrm{L}^{*}\right)$ was highest in Pegasus and Vivlos and lowest (darkest pulp) in Extazy and Esmeralda. As denoted by chroma values $\left(C^{*}\right)$, the pulp was most intensely colored in Extazy and Vivlos and least colored in Esmeralda, Petite and Pegasus. Similar cultivar ranking was observed in both years for the intensity of redness denoted by colorimetric parameter a* (data not shown). Chroma was also marginally higher in response to rootstock TZ148 than Festival but only in the first year of experimentation. The narrowest hue angles denoting the most reddish color were obtained from Extazy and Pegasus, while the widest hue angles denoting the least reddish hue were obtained from Esmeralda. During 10-day storage at $25^{\circ} \mathrm{C}$, there was a slight darkening of the pulp (reduced $\mathrm{L}^{*}$ ), but also an increase in chroma and a widening of hue angle denoting a more intense color but also a slight color transition toward orange-red hue. 
Table 2. Fruit rind thickness, pulp firmness, pulp CIELAB color components (Lightness- $\mathrm{L}^{*}$, Chroma—C* and Hue angle—h), lycopene content, total soluble solids (TSS), and citrulline content in watermelon fruit of cvs. Petite, Vivlos, Pegasus, Extazy and Esmeralda grafted on TZ148 and Festival rootstocks and stored for 10 days at $25^{\circ} \mathrm{C}$. Values represent means $\pm \mathrm{SE}$.

\begin{tabular}{|c|c|c|c|c|c|c|c|c|c|c|c|c|c|c|c|c|c|c|c|c|c|c|c|c|c|c|c|c|c|c|c|}
\hline \multirow{2}{*}{ Source of Variance } & \multirow[b]{2}{*}{ DF } & \multicolumn{4}{|c|}{$\begin{array}{l}\text { Rind } \\
(\mathrm{mm})\end{array}$} & \multicolumn{4}{|c|}{$\begin{array}{c}\text { Firmness } \\
(\mathrm{kg})\end{array}$} & \multicolumn{4}{|c|}{$\begin{array}{c}\text { Lightness- }-L^{*} \\
(0-100)\end{array}$} & \multicolumn{4}{|c|}{ Chroma-C $\mathrm{C}^{*}$} & \multicolumn{4}{|c|}{$\begin{array}{c}\text { Hue angle-h } \\
\text { (degrees) }\end{array}$} & \multicolumn{3}{|c|}{$\begin{array}{c}\text { Lycopene } \\
\left(\mu g^{1}{ }^{1} \mathrm{FW}\right)\end{array}$} & \multicolumn{5}{|c|}{$\begin{array}{l}\text { TSS } \\
(\%)\end{array}$} & \multirow{2}{*}{\multicolumn{2}{|c|}{$\begin{array}{c}\begin{array}{c}\text { Citrulline } \\
\left(\mathrm{mg} \mathrm{g}^{1} \text { ffw. }\right)\end{array} \\
\text { Year } 2 \\
\end{array}$}} \\
\hline & & Year 1 & & Year 2 & & Year 1 & & Year 2 & & Year 1 & & Year 2 & & Year 1 & & Year 2 & & Year 1 & & Year 2 & & Year 1 & & Year 2 & & Year 1 & & Year 2 & & & \\
\hline Storage (S) & 1 & 19.6 & $* * *$ & 63.1 & $* * *$ & 3.4 & ${ }^{*}$ & 1.82613 & $*$ & 27.7 & $* *$ & 7.0 & & 331.9 & $\mathrm{ANOV}_{* *}$ & $\begin{array}{l}\text { VA-Mean S } \\
45.2\end{array}$ & $\begin{array}{c}f \text { puares } \\
* * * \\
* *\end{array}$ & 46.0 & $* * *$ & 19.3 & $* * *$ & 3330.979 & $* * *$ & 434.917 & $* *$ & 6.995868 & $* * *$ & 5.5 & $* * *$ & 0.54 & $* *$ \\
\hline Cultivar (C) & 4 & 63.1 & $* * *$ & 47.4 & $* * *$ & 132.1 & $* *$ & 158.5419 & $* * *$ & 97.2 & $* * *$ & 50.92959 & $* * *$ & 74.8 & $* * *$ & 76.8 & $* * *$ & 53.7 & $* *$ & 19.8 & $* * *$ & 7648.001 & $* * *$ & 4467.337 & $* * *$ & 0.9 & $*$ & 6.1 & $* * *$ & 1.33 & $* * *$ \\
\hline Rootstock (R) & 1 & 15.1 & $* * *$ & 0.9 & & 31.8 & $* * *$ & 46.60413 & $* * *$ & 3.0 & & 7.62237 & & 30.9 & * & 8.5 & & 0.0 & & 7.7 & $* * *$ & 685.403 & $* * *$ & 620.696 & *** & 0.1 & & 0.9 & * & 0.05 & \\
\hline $\mathrm{S} \times \mathrm{C}$ & 4 & 5.4 & $* * *$ & 1.6 & & 0.2 & & 0.11757 & & 2.4 & & 12.11847 & ** & 10.1 & & 1.2 & & 1.8 & & 5.1 & $* * *$ & 436.3065 & $* * *$ & 62.717 & & 0.1 & & 0.2 & & 0.04 & \\
\hline$S \times R$ & 1 & 3.9 & * & 0.6 & & 0.2 & & 0.00204 & & 1.2 & & 32.35032 & $* *$ & 4.0 & & 5.5 & & 0.8 & & 0.2 & & 20.259 & & 201.489 & & 0.0 & & 0.2 & & 0.08 & \\
\hline $\mathrm{C} \times \mathrm{R}$ & 4 & 0.5 & & 2.1 & & 6.0 & $* * *$ & 2.6 & $* * *$ & 10.9 & * & 2.650518 & & 2.4 & & 1.9 & & 1.2 & & 3.4 & $* * *$ & 110.2028 & & 58.5965 & & 0.3 & & 0.3 & & 0.25 & * \\
\hline $\mathrm{S} \times \mathrm{C} \times \mathrm{R}$ & 4 & 2.3 & ** & 0.3 & & 0.2 & & 0.6 & & 3.4 & & 0.579708 & & 2.0 & & 1.8 & & 1.1 & & 0.8 & & 63.263 & & 28.14675 & & 0.3 & & 0.2 & & 0.04 & \\
\hline $\begin{array}{l}\text { Storage } \\
0\end{array}$ & & $12.3+0.4$ & a & $12 \pm 0.3$ & a & $5.4 \pm 0.5$ & a & $5.7 \pm 0.5$ & a & $41.9 \pm 0.5$ & $\mathrm{a}$ & $41.7 \pm 0.4$ & & $30.6 \pm 0.5$ & $\mathrm{~b}$ & $\begin{array}{l}\text { Mean Compa } \\
32.4 \pm 0.4\end{array}$ & $\begin{array}{c}\text { arisons } \\
\mathrm{b}\end{array}$ & $33.7 \pm 0.3$ & $\mathrm{~b}$ & $34.3 \pm 0.2$ & b & $67.4 \pm 3.77$ & b & $69.3 \pm 2.6$ & b & & $\mathrm{a}$ & $11 \pm 0.1$ & a & $33+0$ & $a^{3}$ \\
\hline 10 & & $11.4 \pm 0.3$ & b & $10.2 \pm 0.3$ & b & $5 \pm 0.4$ & b & $5.4 \pm 0.5$ & b & $40.7 \pm 0.4$ & b & $41.2 \pm 0.4$ & & $34.7 \pm 0.5$ & a & $33.9 \pm 0.4$ & $\mathrm{a}$ & $35.2 \pm 0.3$ & a & $35.3 \pm 0.2$ & a & $80.3 \pm 3.08$ & a & $73.8 \pm 2.8$ & a & $10.6 \pm 0.1$ & $\mathrm{~b}$ & $10.5 \pm 0.1$ & b & $3.1 \pm 0.1$ & b \\
\hline & & $130+05$ & & $117+04$ & $\mathrm{~b}$ & $55+02$ & $\mathrm{~b}$ & $57+02$ & & & & $416+06$ & & $298+07$ & & $309+04$ & $c^{\prime}$ & $344+03$ & $c_{c}$ & $354+0$ & & & & & & & & & & & 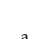 \\
\hline $\begin{array}{l}\text { Petite } \\
\text { Vivlos }\end{array}$ & & $\begin{array}{l}13.0 \pm 0.5 \\
8.9 \pm 0.1\end{array}$ & $\begin{array}{l}\mathrm{b} \\
\mathrm{d}\end{array}$ & $\begin{array}{l}11.7 \pm 0.4 \\
8.8 \pm 0.2\end{array}$ & d & $\begin{array}{l}4.0 \pm 0.1 \\
4.0\end{array}$ & $\begin{array}{l}\mathrm{b} \\
\mathrm{c}\end{array}$ & $\begin{array}{l}5.70 .2 \\
4.1 \pm 0.2\end{array}$ & $\begin{array}{l}\mathrm{b} \\
\mathrm{c}\end{array}$ & $\begin{array}{l}40.9 \pm 0.6 \\
43.4 \pm 0.4\end{array}$ & a & & $\begin{array}{l}\mathrm{b} \\
\mathrm{b}\end{array}$ & & $\begin{array}{l}c \\
a\end{array}$ & & b & & $\mathrm{b}$ & & $\begin{array}{l}\mathrm{b} \\
\mathrm{c}\end{array}$ & & $\begin{array}{l}\mathrm{bc} \\
\mathrm{b}\end{array}$ & $\begin{array}{l}61.9+1.8 \\
72.9+2.2\end{array}$ & $\begin{array}{l}\mathrm{c} \\
\mathrm{b}\end{array}$ & $\begin{array}{l}10.9 \pm 0.2 \\
11.1 \pm 0.1\end{array}$ & ab & $\begin{array}{l}10.4 \pm 0.2 \\
11.2 \pm 0.1\end{array}$ & $\begin{array}{l}\mathrm{b} \\
\mathrm{a}\end{array}$ & $\begin{array}{l}3.7 \pm 0.10 \\
3.1 \pm 0.06\end{array}$ & $\mathrm{a}$ \\
\hline $\begin{array}{l}\text { Vivlos } \\
\text { Pegasus }\end{array}$ & & $\begin{array}{c}8.9 \pm 0.1 \\
12.7 \pm 0.3\end{array}$ & $\begin{array}{l}d \\
b\end{array}$ & $\begin{array}{l}8.8 \pm 0.2 \\
12 \pm 0.3\end{array}$ & $\begin{array}{l}d \\
b\end{array}$ & $\begin{array}{l}4.0 \pm 0.1 \\
3.0 \pm 0.1\end{array}$ & $\begin{array}{l}c \\
d\end{array}$ & $\begin{array}{l}4.1 \pm 0.2 \\
3.3 \pm 0.2\end{array}$ & $\begin{array}{l}c \\
d\end{array}$ & $\begin{array}{l}43.4 \pm 0.4 \\
44.1 \pm 0.5\end{array}$ & a & $\begin{array}{l}41.6 \pm 0.4 \\
44.2 \pm 0.4\end{array}$ & $\begin{array}{l}\mathrm{b} \\
\mathrm{a}\end{array}$ & $\begin{array}{l}34.9 \pm 0.7 \\
31.9 \pm 0.6\end{array}$ & $\begin{array}{l}\mathrm{a} \\
\mathrm{bc}\end{array}$ & $\begin{array}{l}34.6 \pm 0.4 \\
32.0 \pm 0.5\end{array}$ & $\begin{array}{l}\mathrm{b} \\
\mathrm{c}\end{array}$ & $\begin{array}{l}35.2 \pm 0.2 \\
32.8 \pm 0.1\end{array}$ & $\begin{array}{l}\mathrm{b} \\
\mathrm{d}\end{array}$ & $\begin{array}{l}34.1 \pm 0.2 \\
34.2 \pm 0.2\end{array}$ & $\begin{array}{l}c \\
c\end{array}$ & $\begin{array}{l}69.4 \pm 4.5 \\
64.1 \pm 1.6\end{array}$ & $\begin{array}{l}\mathrm{b} \\
\mathrm{bc}\end{array}$ & $\begin{array}{l}72.9 \pm 2.2 \\
60.2 \pm 1.9\end{array}$ & $\begin{array}{l}\mathrm{b} \\
\mathrm{c}\end{array}$ & $\begin{array}{l}11.1 \pm 0.1 \\
11 \pm 0.2\end{array}$ & $\begin{array}{l}\mathrm{a} \\
\mathrm{ab}\end{array}$ & $\begin{array}{l}11.2 \pm 0.1 \\
11.4 \pm 0.1\end{array}$ & $\begin{array}{l}\mathrm{a} \\
\mathrm{a}\end{array}$ & $\begin{array}{l}3.1 \pm 0.06 \\
2.9 \pm 0.07\end{array}$ & $\begin{array}{c}\mathrm{bc} \\
\mathrm{c}\end{array}$ \\
\hline Extazy & & $13.8 \pm 0.3$ & a & $13.5 \pm 0.4$ & a & $10 \pm 0.6$ & a & $11.0 \pm 0.5$ & a & $38.1 \pm 0.4$ & c & $40.2 \pm 0.6$ & $\mathrm{bc}$ & $34.8 \pm 0.5$ & a & $36.6 \pm 0.5$ & a & $32.8 \pm 0.3$ & d & $33.5 \pm 0.4$ & c & $112.3 \pm 2.8$ & a & $102.9 \pm 3$ & a & $10.5 \pm 0.2$ & $\mathrm{~b}$ & $9.8 \pm 0.2$ & c & $3.2 \pm 0.08$ & b \\
\hline Esmeralda & & $10.9 \pm 0.2$ & c & $10.1 \pm 0.3$ & c & $3.3 \pm 0.1$ & $\mathrm{~cd}$ & $3.4 \pm 0.2$ & d & $40.0 \pm 0.5$ & b & $39.6 \pm 0.5$ & c & $32.1 \pm 1.1$ & b & $32.4 \pm 0.4$ & c & $37.1 \pm 0.4$ & a & $36.3 \pm 0.2$ & a & $58.3 \pm 2.2$ & c & $64.8 \pm 1.3$ & c & $10.9 \pm 0.1$ & $\mathrm{ab}$ & $10.7 \pm 0.1$ & $\mathrm{~b}$ & $3.2 \pm 0.06$ & b \\
\hline Rootstock & & & & & & & & & & & & & & & & & & & & & & & & & & & & & & & \\
\hline TZ148 & & $12.3 \pm 0.4$ & a & $11.1 \pm 0.3$ & & $5.8 \pm 0.5$ & a & $5.9 \pm 0.5$ & & $41.5 \pm 0.5$ & & $41.7 \pm 0.4$ & & & a & $33.4 \pm 0.4$ & & $34.4 \pm 0.3$ & & & b & & $a$ & & $\mathrm{a}$ & $10.9 \pm 0.1$ & & $10.7 \pm 0.1$ & $\mathrm{~b}$ & $3.2 \pm 0.1$ & \\
\hline Festival & & $11.4 \pm 0.3$ & $\mathrm{~b}$ & $11.3 \pm 0.4$ & & $4.5 \pm 0.3$ & $\mathrm{~b}$ & $4.8 \pm 0.4$ & $\mathrm{~b}$ & $41.1 \pm 0.5$ & & $41.1 \pm 0.4$ & & $32.1 \pm 0.6$ & b & $32.9 \pm 0.4$ & & $34.5 \pm 0.3$ & & $35.0 \pm 0.3$ & $\mathrm{a}$ & $70.9 \pm 3.11$ & $\mathrm{~b}$ & $69.7 \pm 2.9$ & $\mathrm{~b}$ & $10.8 \pm 0.1$ & & $10.8 \pm 0.1$ & $\mathrm{a}$ & $3.2 \pm 0.1$ & \\
\hline
\end{tabular}

$\mathrm{DF}=$ degrees of freedom. ${ }^{*}$ Significant effect at the 0.05 level, ${ }^{* *} 0.01$ level, ${ }^{* * *} 0.001$ level. Means within each column followed by different letters denote significant differences $(p<0.05)$ according to the Tukey-Kramer HSD test. 


\subsection{Compositional Characteristics of Watermelon Fruit}

Pulp lycopene content correlated significantly with pulp chroma in both years $\left(\mathrm{r}_{\text {year1 }}=0.53\right.$, $p<0.001$ and $r_{\text {year } 2}=0.72, p<0.001$ ). Scion cultivar effect was the most influential on pulp lycopene content compared to rootstock and storage effects (Table 2). The range of lycopene content in the scion cultivars was widened by Extazy, which attained $95 \%$ and $57 \%$ higher lycopene than the mean content of the rest of the cultivars in year1 and year2, respectively. The outstanding lycopene content of Extazy (102.8-112.3 $\left.\mathrm{g} \mathrm{g} \mathrm{g}^{-1}\right)$ also rendered the differences among the rest of the cultivars non-significant. Variation among the rest of the cultivars was indeed limited, though it is worth noting that the mini diploid cultivars Esmeralda and Vivlos had the most variable lycopene content between years. With respect to rootstock, in both years the mean lycopene content of the scions grafted onto interspecific rootstock TZ148 was higher than that obtained on the Lagenaria rootstock Festival. Storage at $25^{\circ} \mathrm{C}$ for 10 days increased pulp lycopene in both years, however this effect was more pronounced in the first year. The content of the pulp in the non-essential amino acid citrulline was influenced by the scion cultivar and by storage but not by the choice of rootstock (Table 2). Variation in mean citrulline content among cultivars ranged from $2.9 \pm 0.1 \mu \mathrm{g} \mathrm{g}^{-1}$ f.w. in Pegasus to $3.7 \pm 0.1 \mu \mathrm{g} \mathrm{g}{ }^{-1}$ f.w. in Petite. During storage, the citrulline concentration in the pulp declined, however the reduction was of limited scale, amounting to $6.1 \%$.

The TSS content of the juice was influenced mostly by cultivar and storage and least by rootstock (Table 3). Variation in TSS among cultivars was more limited in the first year compared to the second. In both years, Extazy had the lowest TSS (9.8-10.5\%) whereas Pegasus and Vivlos had the highest (11.0-11.4\%). Overall, diploid cultivars had higher TSS than the seedless cultivars. Rootstock had no effect on TSS during the first year and only a marginal effect during the second when TZ148 resulted in slightly lower TSS than Festival. Very similar effects to those on TSS were observed with respect to the total sugar content of the juice (Table 3). Extazy had the lowest sugars and scions grafted on Festival yielded slightly higher sugars than those on TZ148. Mean total sugar content declined significantly with storage in both years with a sharper drop observed in the first than the second year. Fructose, glucose and sucrose varied significantly in response to storage and scion cultivar and were least affected by rootstock. Fructose was higher in the mini diploid cultivars Vivlos and Esmeralda than the mini seedless Extazy and Petite. Fructose was not affected by rootstock in either year. Storage had a significant effect on fructose which was reduced after 10 days at $25^{\circ} \mathrm{C}$ by $12.4 \%$ as a two-year mean. Glucose was also lowest in Extazy and Petite and highest in Esmeralda and Vivlos. Significant cultivar-rootstock interaction was observed for glucose as Festival induced higher glucose content than TZ148 in the first year whereas the opposite was observed in the second year. Storage reduced glucose by $39.7 \%$ and $42.3 \%$ in the first and second year, respectively. Sucrose was highest in Pegasus and Extazy in the first year and in Pegasus and Petite in the second. Among the mini cultivars, sucrose in proportion to the reducing sugars was more abundant in the seeded than the seedless cultivars. Significant cultivar-rootstock interaction was observed for sucrose as TZ148 induced higher glucose content than Festival in the first year whereas the opposite was observed in the second year. As opposed to the levels of reducing sugars, sucrose levels increase postharvest significantly, amounting to an average increase of $57.2 \%$ between the two years. Variation in the proportions of the three sugars was reflected in the sweetness index of the pulp. The highest sweetness index was observed in Vivlos and Esmeralda and the lowest in Extazy. The watermelon pulp acidity as reflected in the juice $\mathrm{pH}$ showed limited variation across cultivars, with no differences observed in the second year. Rootstock affected juice $\mathrm{pH}$ only in the second year with slightly more acidic juice obtained from watermelons grafted onto TZ148. A significant drop in acidity was observed in both years postharvest. 
Table 3. Fructose, glucose, sucrose, total sugars, sweetness index and $\mathrm{pH}$ in watermelon fruit of cvs. Petite, Vivlos, Pegasus, Extazy and Esmeralda grafted on TZ148 and Festival rootstocks and stored for 10 days at $25^{\circ} \mathrm{C}$. Values represent means $\pm \mathrm{SE}$.

\begin{tabular}{|c|c|c|c|c|c|c|c|c|c|c|c|c|c|c|c|c|c|c|c|c|c|c|c|c|c|c|}
\hline \multirow{3}{*}{$\begin{array}{l}\text { Source of } \\
\text { Variance }\end{array}$} & \multicolumn{5}{|c|}{ Fructose } & \multicolumn{4}{|c|}{ Glucose } & \multicolumn{4}{|c|}{ Sucrose } & \multicolumn{3}{|c|}{ Total Sugars } & \multicolumn{5}{|c|}{ Sweetness Index } & \multicolumn{5}{|c|}{$\mathrm{pH}$} \\
\hline & \multicolumn{5}{|c|}{$(\mathrm{mg} / \mathrm{mL})$} & \multicolumn{3}{|c|}{$(\mathrm{mg} / \mathrm{mL})$} & & \multicolumn{4}{|c|}{$(\mathrm{mg} / \mathrm{mL})$} & \multicolumn{4}{|c|}{$(\mathrm{mg} / \mathrm{mL})$} & \multirow[b]{2}{*}{ Year 1} & \multirow{2}{*}{\multicolumn{3}{|c|}{ Year 2}} & \multirow{2}{*}{\multicolumn{2}{|c|}{ Year 1}} & \multirow{2}{*}{\multicolumn{3}{|c|}{ Year 2}} \\
\hline & DF & Year 1 & & Year 2 & & Year 1 & & Year 2 & & Year 1 & & Year 2 & & Year 1 & & Year 2 & & & & & & & & & & \\
\hline & & \multicolumn{25}{|c|}{ ANOVA-Mean Squares } \\
\hline Storage (S) & 1 & 12.65386 & $* * *$ & 1.295732 & $* * *$ & 23.4204 & $* * *$ & 32.74034 & $* * *$ & 37.6 & $* * *$ & 26.82 & $* * *$ & 5.11 & $* * *$ & 2.83 & $* * *$ & $7 \times 10^{6}$ & $* * *$ & $2 \times 10^{5}$ & & & $\times 10^{-1}$ & $* * *$ & $2.1 \times 10^{-1}$ & $* * *$ \\
\hline Rootstock (R) & 1 & 0.039605 & & 0.176574 & & 0.723546 & $* *$ & 0.382525 & * & 1.5 & * & 5.09 & $* * *$ & 0.03 & & 1.48 & * & $1 \times 10^{5}$ & & $1 \times 10^{6}$ & * & & $\times 10^{-5}$ & & $9.4 \times 10^{-2}$ & $* * *$ \\
\hline $\mathrm{S} \times \mathrm{C}$ & 4 & 0.365094 & $* * *$ & 0.233492 & * & 0.212348 & * & 0.997868 & $* * *$ & 0.6 & & 2.00 & $* * *$ & 0.13 & & 0.31 & & $3 \times 10^{5}$ & & $6 \times 10^{5}$ & & & $\times 10^{-3}$ & & $2.9 \times 10^{-2}$ & ** \\
\hline$S \times R$ & 1 & 0.166714 & & 0.424619 & $*$ & 0.117464 & & 0.001721 & & 0.1 & & 0.59 & & 0.15 & & 0.01 & & $3 \times 10^{5}$ & & $8 \times 10^{4}$ & & & $\times 10^{-3}$ & & $2.7 \times 10^{-3}$ & \\
\hline $\mathrm{C} \times \mathrm{R}$ & 4 & 0.101591 & & 0.118581 & & 0.073288 & & 0.159175 & & 0.3 & & 1.02 & * & 0.10 & & 0.27 & & $2 \times 10^{5}$ & & $3 \times 10^{5}$ & & & $\times 10^{-3}$ & & $5.1 \times 10^{-3}$ & \\
\hline$S \times C \times R$ & 4 & 0.102472 & & 0.096792 & & 0.157366 & & 0.116874 & & 0.1 & & 0.29 & & 0.34 & & 0.07 & & $4 \times 10^{5}$ & & $9 \times 10^{4}$ & & & $\times 10^{-3}$ & & $2.3 \times 10^{-3}$ & \\
\hline Storage & & & & & & & & & & & & & & an Compariso & & & & & & & & & & & & \\
\hline 10 & & $35.5 \pm 1.16$ & $\mathrm{~b}$ & $36.9 \pm 1.2$ & b & $16.4 \pm 0.76$ & b & $17.8 \pm 0.8$ & b & $36.5 \pm 1.67$ & a & $33.1 \pm 1.9$ & a & $88.3 \pm 0.74$ & $\mathrm{~b}$ & $87.7 \pm 1.3$ & b & $10341 \pm 97$ & b & $10314 \pm 15$ & & & $5.6 \pm 0.01$ & a & $5.6 \pm 0.02$ & a \\
\hline \multicolumn{27}{|l|}{ Cultivar } \\
\hline Petite & & $38.0 \pm 1.8$ & $\mathrm{~b}$ & $33.6 \pm 1.2$ & $\mathrm{~b}$ & $18.9 \pm 2.0$ & $\mathrm{bc}$ & $18.8 \pm 1.4$ & $\mathrm{c}$ & $33.4 \pm 2.8$ & $\mathrm{~b}$ & $33.8 \pm 2.6$ & $\mathrm{a}$ & $90.4 \pm 1.7$ & $\mathrm{ab}$ & $86.2 \pm 1.4$ & $\mathrm{~b}$ & $10605 \pm 196$ & $\mathrm{bc}$ & $9943.6 \pm 13$ & & $\mathrm{~b}$ & $5.5 \pm 0.03$ & $\mathrm{~b}$ & $5.5 \pm 0.02$ & \\
\hline Vivlos & & $\begin{array}{l}46.4 \pm 1.1 \\
46.4\end{array}$ & a & $\begin{array}{l}44.1 \pm 0.9 \\
44.1\end{array}$ & a & $25.7 \pm 1.5$ & a & $28.7 \pm 2.6$ & a & $\begin{array}{l}21.1 \pm 2.0 \\
21.0\end{array}$ & c & $21.9 \pm 2.8$ & b & $93.2 \pm 1.1$ & $\mathrm{a}$ & $94.6 \pm 1.3$ & a & $11147 \pm 115$ & a & $11064.9 \pm 12$ & & a & $5.4 \pm 0.03$ & b & $5.5 \pm 0.02$ & $\begin{array}{l}a \\
a\end{array}$ \\
\hline Pegasus & & $\begin{array}{l}\text { bo.4 } 4.1 .1 \\
34.1 \pm 1.2\end{array}$ & c & $\begin{array}{l}32.4 \pm 0.7 \\
32.4\end{array}$ & b & $\begin{array}{l}21.4 \pm 1.6 \\
21.6\end{array}$ & b & $\begin{array}{l}25.4 \pm 2.0 \\
25.2\end{array}$ & b & $\begin{array}{l}36.3 \pm 2.5 \\
36.3\end{array}$ & $a b$ & $\begin{array}{l}31.9 \pm 2.0 \\
37.9 \pm 2.7\end{array}$ & a & $\begin{array}{l}91.7 \pm 1.3 \\
91.7\end{array}$ & $\begin{array}{l}\mathrm{a} \\
\mathrm{ab}\end{array}$ & $\begin{array}{l}95.7 \pm \pm 1.0 \\
95.7\end{array}$ & $\begin{array}{l}\mathrm{d} \\
\mathrm{a}\end{array}$ & $10436 \pm 132$ & $\begin{array}{l}\mathrm{a} \\
\mathrm{cd}\end{array}$ & $\begin{array}{l}10602.4 \pm 12 \\
\end{array}$ & & $\begin{array}{l}\mathrm{a} \\
\mathrm{a}\end{array}$ & $\begin{array}{l}.4 \pm 0.00 \\
5.5 \pm 0.02\end{array}$ & b & $\begin{array}{l}5.0 \pm 0.02 \\
5.5 \pm 0.01\end{array}$ & $\begin{array}{l}\mathrm{d} \\
\mathrm{a}\end{array}$ \\
\hline Extazy & & $\begin{array}{l}\text { 44.11 } \pm 1.2 \\
31.8 \pm 1.0\end{array}$ & c & $\begin{array}{l}32.4 \pm 0.7 \\
33.2 \pm 0.6\end{array}$ & $\begin{array}{l}\mathrm{b} \\
\mathrm{b}\end{array}$ & $\begin{array}{l}11.4 \pm \pm 1.6 \\
16.7 \pm 1.2\end{array}$ & $\begin{array}{l}\text { b } \\
\text { c }\end{array}$ & $\begin{array}{l}25.4 \pm 2.2 \\
18.2 \pm 1.4\end{array}$ & $\begin{array}{l}\mathrm{b} \\
\mathrm{c}\end{array}$ & $\begin{array}{l}\text { o. } \\
39.2 \pm 2.0\end{array}$ & $\begin{array}{l}\mathrm{ab} \\
\mathrm{a}\end{array}$ & $\begin{array}{l}27.4 \pm 1.8 \\
27.9\end{array}$ & $\begin{array}{l}\mathrm{a} \\
\mathrm{b}\end{array}$ & $\begin{array}{l}11.1 \pm \pm .3 \\
87.6 \pm 1.3\end{array}$ & $\begin{array}{l}\mathrm{ab} \\
\mathrm{b}\end{array}$ & $78.7 \pm 1.9$ & c & $\begin{array}{l}10043 \pm 134 \\
10043\end{array}$ & d & $\begin{array}{l}9188.7 \pm 19 \\
9180\end{array}$ & & $\begin{array}{l}\mathrm{a} \\
\mathrm{c}\end{array}$ & $\begin{array}{l}5.3 \pm 0.02 \\
5.6 \pm 0.03\end{array}$ & $\begin{array}{l}\mathrm{b} \\
\mathrm{a}\end{array}$ & $\begin{array}{l}5.3 \pm 0.01 \\
5.5 \pm 0.04\end{array}$ & $\begin{array}{l}a \\
a\end{array}$ \\
\hline Esmeralda & & $47.0 \pm 1.1$ & a & $45.6 \pm 0.7$ & a & $26.1 \pm 1.7$ & a & $29.2 \pm 1.6$ & a & $18.4 \pm 2.0$ & c & $16.3 \pm 1.5$ & c & $91.5 \pm 1.6$ & $\mathrm{ab}$ & $91.1 \pm 0.9$ & a & $11000 \pm 170$ & $a b$ & $10781.9 \pm 9$ & & a & $5.5 \pm 0.04$ & b & $5.5 \pm 0.04$ & a \\
\hline \multicolumn{27}{|l|}{ Rootstock } \\
\hline TZ148 & & $39.2 \pm 1.33$ & & $38.8 \pm 1$ & & $20.8 \pm 1.13$ & $\mathrm{~b}$ & $25.3 \pm 1.3$ & $\mathrm{a}$ & $31.0 \pm 1.9$ & $\mathrm{a}$ & $24.5 \pm 1.8$ & $\mathrm{~b}$ & $91.1 \pm 0.90$ & & $88.6 \pm 1.3$ & $\mathrm{~b}$ & $10684 \pm 119$ & & $10273 \pm 13$ & & $\mathrm{~b}$ & $5.5 \pm 0.02$ & & $5.5 \pm 0.02$ & $\mathrm{~b}$ \\
\hline Festival & & $39.7 \pm 1.21$ & & $\begin{array}{l}3.0 \pm 1 \\
37.3 \pm 1.1\end{array}$ & & $22.7 \pm 1.16$ & a & $23.3 \pm 1.5$ & b & $28.3 \pm 2.0$ & b & $29.9 \pm 2.0$ & a & $90.7 \pm 0.93$ & & $90.5 \pm 1.2$ & a & $10608 \pm 107$ & & $10439 \pm 12$ & & a & $5.5 \pm 0.02$ & & $5.6 \pm 0.02$ & a \\
\hline
\end{tabular}

$\mathrm{DF}=$ degrees of freedom. ${ }^{*}$ Significant effect at the 0.05 level, ${ }^{* *} 0.01$ level, ${ }^{* * *} 0.001$ level. Means within each column followed by different letters denote significant differences $(p<0.05)$ according to the Tukey-Kramer HSD test. 


\section{Discussion}

Fruit morphometric characteristics such as weight and shape were the ones affected least by the choice of rootstock. Fruit shape in particular was a trait defined almost exclusively by the scion genotype. These findings corroborate previous works demonstrating the limited variation encountered in these traits in response to different rootstocks and also between grafted and non-grafted material [1]. By contrast, crop performance was strongly influenced by the choice of rootstock. In this respect, the higher yield obtained on Cucurbita maxima $\times$ C. moschata interspecific rootstock TZ148 reflects the vigorous habit of interspecific rootstocks in comparison to the weaker Lagenaria rootstocks, such as Festival. These findings underpin previous reports on the superior crop performance imparted by interspecific rootstocks, provided the absence of physiological incompatibility between scion and rootstock [14-16]. Fruit weight and fruit number incurred a limited rootstock effect. Cultivar genotype largely defined variation in these traits with the large-fruited diploid Pegasus producing higher yield than the mini cultivars, of which the triploid ones were more profuse than the diploid ones. Moreover, watermelon yield may present significant annual variation, as presently demonstrated by all scions on both rootstocks, which has been attributed by previous researchers to the variability of climatic and soil conditions $[17,18]$. It is noteworthy, however, that mean yield varied between years by $12.2 \%$ on TZ148 compared to $36.3 \%$ on Festival, which is an indication of the stable vigor afforded by interspecific rootstocks. Nonetheless, all of the scion-rootstock combinations examined exceeded the regional yield average of 52 tons $\mathrm{ha}^{-1}$ in both years $[19,20]$.

Morphological and visual characteristics of watermelon fruit may substantially influence the perception of quality and ultimately consumer choice. Rind thickness is a morphological trait previously described as responsive to cultural practices that affect maturation, including grafting $[1,11]$. As the rind grows progressively thinner with maturation, watermelon harvest maturity is a defining factor. Contrasting literature on the impact of grafting on rind thickness may thus be interpreted partly in the context of rootstock effects on the ripening process but may also be attributed to the absence of strict maturity standardization during sampling. The current study corroborates that rootstock effect on watermelon rind thickness is generally limited compared to the effect of the scion cultivar [21]. Little emphasis has been given previously on the postharvest change in watermelon rind thickness $[19,22]$. The current study indicates that it is reduced during storage, which renders the impact of rootstocks on rind thickness, presently evidenced in the thicker rind induced by interspecific TZ148 over Lagenaria rootstock Festival, significant for watermelon shelf-life.

Pulp firmness is a significant sensory quality trait of watermelon fruit shown to respond to heterografting on various types of rootstocks. Commercial interspecific (C. maxima $\times$ C. moschata) rootstocks tend to increase pulp firmness, as demonstrated by several previous studies $[10,11,23,24]$. Loss of firmness in response to heterografting has been more often reported with particular Lagenaria siceraria and Cucurbita argyrosperma rootstocks $[25,26]$. The present study focused on the impact of interspecific and Lagenaria gourd rootstocks on scions of differing ploidy, therefore homeograft and self-rooted controls were not used. It was nevertheless observed that the more vigorous interspecific rootstock TZ148 induced notably higher pulp firmness (30.1\% higher as a two-year average) than the Lagenaria rootstock Festival, which underpins previous findings on the superiority of interspecific hybrids for this trait. Gourd rootstocks have had for the most part no effect or very limited and variable effect on pulp firmness $[15,24,25,27]$. Pulp firmness was also found significantly higher in seedless triploid cultivars compared to diploid ones despite the fact that texture analysis was performed not in the locular areas but around the core of the fruit using a set of eight probes in circular $42 \mathrm{~mm}$-diameter arrangement [11]. Pulp firmness has been linked to increased density of parenchymatic cells containing higher alcohol-insoluble and water-insoluble cell wall fractions [28]. The higher firmness presently observed in triploid cultivars, noted also by certain previous researchers [29], might thus be related to higher density of parenchymatic cells bearing more abundant alcohol- and water-insoluble fractions, a hypothesis that warrants further investigation involving cell wall fractionation. Finally, the effect of storage on firmness was significant but limited compared to that of scion cultivar and rootstock. 
Nonetheless, previous work has demonstrated that sensory quality and shelf-life of watermelon is limited to less than two weeks under ambient conditions owing among others to declining pulp firmness, [1]. In light of this, grafting on interspecific hybrid rootstocks might present a significant advantage in terms shelf-life and the same might be the case for triploid over diploid scions.

Watermelon pulp color is configured principally by the accumulation of carotenoids during ripening $[11,30,31]$. Over $90 \%$ of the carotenoid content of red-fleshed cultivars accounts for lycopene, with about $10 \%$ being in the cis isomeric bioavailable form and the rest in the trans form [32]. The highly significant correlation of pulp colorimetry with lycopene content, evidenced in both years of the present study, is common among red-fleshed cultivars; however, pulp chromaticity may not always correlate significantly enough with lycopene content owing to the presence of $\beta$-carotene, which varies with cultivar, maturity and postharvest storage $[1,33]$. The presence of Extazy among the examined scions, which had an outstanding lycopene content $\left(102.8 \mu \mathrm{g} \mathrm{g}^{-1} \mathrm{fw}\right)$, confounded the effects of rootstock and storage compared to the scion effect. Nonetheless, scion genotype is the most determining factor for carotenoid composition of watermelon fruit with lycopene varying widely among red-fleshed cultivars $\left(20-125 \mu \mathrm{g} \mathrm{g}^{-1} \mathrm{fw}\right)$, presently exemplified by the triploid Extazy [32,34]. The current results, moreover, indicate that ploidy is not a determining factor for lycopene content since triploid cultivars diverged significantly (61.9-102.8 $\left.\mathrm{\mu g} \mathrm{g}^{-1} \mathrm{fw}\right)$. Grafting, on the other hand, especially on C. maxima $\times$ C. moschata interspecific rootstocks $[11,21,35,36]$ and less frequently on L. siceraria cultivars [37], has been found to increase lycopene content in watermelon fruit. In both years of the present study, the lycopene content of the scions grafted onto the interspecific rootstock TZ148 was higher than that obtained on the Lagenaria rootstock Festival. This might be attributed in part to a higher density of parenchymatic cells induced by TZ148 since lycopene is a fat-soluble membrane-bound pigment $[11,28]$. Finally, postharvest storage at $25^{\circ} \mathrm{C}$ for 10 days increased pulp lycopene in both years of the present study, corroborating previous reports that lycopene synthesis continues and lycopene levels peak postharvest although watermelon is a non-climacteric fruit $[1,19]$. The postharvest increase in chroma $\left(C^{*}\right)$ was accompanied, however, by a wider hue angle signifying a color transition toward the orange-red hue characteristic of over-ripening. This transition might stem from the conversion of lycopene to $\beta$-carotene or from lycopene degradation products [38].

Citrulline is arguably the most important bioactive molecule found in watermelon fruit after lycopene [39]. Previous work has demonstrated that grafting watermelon on interspecific hybrid rootstocks may increase citrulline concentration in the pulp compared to the non-grafted control [1]. The current study indicates that the choice of rootstock between an interspecific hybrid and a Lagenaria rootstock has no effect on citrulline. In fact, the greatest source of variation was the scion cultivar whereas limited decline in citrulline was observed postharvest. It appears therefore that the increase in citrulline content obtained with grafting vs. self-rooted watermelon is largely offset by postharvest decline, which was not previously reported for non-grafted watermelon. However, given the relative abundance of citrulline in watermelon rind, the thicker rind induced by TZ148 may provide more substrate for industrially extracting the non-essential amino acid citrulline that garners significant pharmacological interest [39].

The soluble solids content of watermelon juice is configured primarily by soluble sugars although non-carbohydrate components such as organic acids, water-soluble soluble pectins and pigments may also influence the refractive index of the juice $[40,41]$. In the present study, the TSS and the total sugars of the juice were influenced mostly by cultivar and storage. Diploid cultivars attained overall higher TSS and total sugars than the seedless cultivars, however all scions delivered TSS values near 10\% or higher, which is considered a prerequisite for consumer acceptability [42]. Postharvest storage at ambient temperature resulted in a significant decline in TSS and total sugars, which renders the postharvest handling of watermelons critical for sensory quality, especially for triploid cultivars of lower sweetness. In this respect, Kyriacou et al. [1] highlighted in previous work the importance of optimal harvest maturity for watermelon grafted on vigorous rootstocks that delay ripening, when prolonged postharvest storage ( $>10$ days) at ambient conditions is unavoidable. From a physiological point of 
view, it is noteworthy that glucose and fructose levels decreased during storage as opposed to sucrose, which increased owing most probably to the postharvest activity of ripening-related enzymes such as sucrose synthase. This observation, in conjunction with the postharvest accumulation of lycopene discussed above, sheds new light onto the postharvest physiology of watermelon, otherwise considered a non-climacteric fruit.

The TSS and total sugars of watermelon were generally not decreased by grafting on most commercial C. maxima $\times$ C. moschata rootstocks $[10,23,36]$, whereas scion response to grafting seems more rootstock-specific with Lagenaria siceraria cultivars and landraces $[14,37,43]$. The marginally lower total sugars content observed with TZ148 in the second year of the current study likely relate to the higher fruit load supported by this rootstock and a possible slight delay in ripening compared to the Lagenaria rootstock Festival. This is further supported by the higher hexoses-to-sucrose ratio observed with TZ148 in the second year, given that the common sugar motif observed during watermelon ripening is that of sucrose accumulating at the expense of hexoses [11]. At any rate, the non-significant or marginal rootstock effect on TSS and total sugars renders interspecific TZ148 an advantageous rootstock over Lagenaria Festival on account of higher yield, firmness and lycopene content.

\section{Conclusions}

Fruit morphometric characteristics were affected least by the choice of rootstock. However, the more vigorous interspecific rootstock delivered higher and more stable yield across seasons than gourd rootstock, which highlights the superior crop performance imparted by interspecific rootstocks, provided the absence of physiological rootstock-scion incompatibility. Interspecific rootstock also induced thicker rind and higher pulp firmness, both of which improve shelf-life. Pulp firmness was higher in seedless triploid cultivars compared to diploid ones, which might relate to higher density of parenchymatic cells. Current results indicate that scion genotype but not ploidy level is the most determining factor for carotenoid composition of watermelon fruit. Moreover, interspecific rootstock induced higher fruit lycopene content than gourd rootstock. Ambient postharvest storage for 10 days increased pulp lycopene, corroborating previous reports that lycopene synthesis continues and lycopene levels peak postharvest although watermelon is a non-climacteric fruit. Diploid cultivars attained overall higher TSS and total sugars than seedless cultivars; storage, however, reduced both, which renders the postharvest handling of triploid cultivars particularly prone to loss of sensory quality. Reducing sugars decreased during storage while sucrose increased. This observation in conjunction with the postharvest accumulation of lycopene sheds new light onto the postharvest physiology of watermelon, otherwise considered a non-climacteric fruit. Minimal reduction in sugars by interspecific rootstock was related to higher fruit load and possible slight delay in ripening compared to gourd, further supported by the higher hexoses-to-sucrose ratio observed with the former. The marginal rootstock effect on sugars renders interspecific rootstock advantageous over gourd on account of higher yield, firmness and lycopene content.

Author Contributions: Conceptualization, G.A.S., M.C.K. and Y.R.; methodology, G.A.S. and M.C.K.; formal analysis, G.A.S. and M.C.K.; investigation, G.A.S. and M.C.K.; writing-review and editing, G.A.S., M.C.K. and Y.R.; supervision, M.C.K. and Y.R.; All authors have read and agreed to the published version of the manuscript.

Funding: This research received no external funding.

Conflicts of Interest: The authors declare no conflict of interest.

\section{References}

1. Kyriacou, M.C.; Soteriou, G.A.; Rouphael, Y.; Siomos, A.S.; Gerasopoulos, D. Configuration of watermelon fruit quality in response to rootstock-mediated harvest maturity and postharvest storage. J. Sci. Food Agric. 2016, 96, 2400-2409. [CrossRef] [PubMed]

2. Savvas, D.; Colla, G.; Rouphael, Y.; Schwarz, D. Amelioration of heavy metal and nutrient stress in fruit vegetables by grafting. Sci. Hortic. 2010, 127, 156-161. [CrossRef] 
3. Schwarz, D.; Rouphael, Y.; Colla, G.; Venema, J.H. Grafting as a tool to improve tolerance of vegetables to abiotic stresses: Thermal stress, water stress and organic pollutants. Sci. Hortic. 2010, 127, 162-171. [CrossRef]

4. Borgognone, D.; Colla, G.; Rouphael, Y.; Cardarelli, M.; Rea, E.; Schwarz, D. Effect of nitrogen form and nutrient solution $\mathrm{pH}$ on growth and mineral composition of self-grafted and grafted tomatoes. Sci. Hortic. 2013, 149, 61-69. [CrossRef]

5. Rouphael, Y.; Kyriacou, M.C.; Colla, G. Vegetable grafting: A toolbox for securing yield stability under multiple stress conditions. Front. Plant Sci. 2018, 8, 2255. [CrossRef]

6. Causse, M.; Saliba-Colombani, V.; Lecomte, L.; Duffé, P.; Rousselle, P.; Buret, M. QTL analysis of fruit quality in fresh market tomato: A few chromosome regions control the variation of sensory and instrumental traits. J. Exp. Bot. 2002, 53, 2089-2098. [CrossRef]

7. Chilsom, D.N.; Picha, D.H. Effect of storage temperature on sugar and organic acid contents of watermelon. HortScience 1986, 21, 1031-1033.

8. Colla, G.; Pérez-Alfocea, F.; Schwarz, D. Vegetable grafting: Principles and practices. CABI 2017. [CrossRef]

9. Kyriacou, M.C.; Soteriou, G.A. Postharvest change in compositional, visual and textural quality of grafted watermelon cultivars. Acta Hortic. 2012, 934, 985-992. [CrossRef]

10. Soteriou, G.A.; Kyriacou, M.C. Rootstock-mediated effects on watermelon field performance and fruit quality characteristics. Int. J. Veg. Sci. 2015, 21, 344-362. [CrossRef]

11. Soteriou, G.A.; Kyriacou, M.C.; Siomos, A.S.; Gerasopoulos, D. Evolution of watermelon fruit physicochemical and phytochemical composition during ripening as affected by grafting. Food Chem. 2014, 165, 282-289. [CrossRef] [PubMed]

12. McGuire, R.G. Reporting of objective color measurements. HortScience 1992, 27, 1254-1255. [CrossRef]

13. Perkins-Veazie, P.; Collins, J.K.; Pair, S.D.; Roberts, W. Lycopene content differs among red-fleshed watermelon cultivars. J. Sci. Food Agric. 2001, 81, 983-987. [CrossRef]

14. Yetisir, H.; Sari, N. Effect of different rootstock on plant growth, yield and quality of watermelon. Aust. J. Exp. Agric. 2003, 43, 1269-1274. [CrossRef]

15. Yetisir, H.; Sari, N.; Yncel, S. Rootstock resistance to Fusarium wilt and effect on watermelon fruit yield and quality. Phytoparasitica 2003, 31, 163-169. [CrossRef]

16. Soteriou, G.A.; Papayiannis, L.C.; Kyriacou, M.C. Indexing melon physiological decline to fruit quality and vine morphometric parameters. Sci. Hortic. 2016, 203, 207-215. [CrossRef]

17. Goreta Ban, S.; Zanic, K.; Dumiciv, G.; Raspudic, E.; Vuletin Selak, G.; Ban, D. Growth and yield of grafted cucumbers in soil infested with root-knot nematodes. Chil. J. Agric. Res. 2014, 74, 29-34. [CrossRef]

18. Huitron, M.V.; Diaz, M.; Dianez, F.; Camacho, F. The effect of various rootstocks on triploid watermelon yield and qualify. J. Food Agric. Environ. 2007, 5, 344-348.

19. Kyriacou, M.C.; Soteriou, G. Quality and postharvest performance of watermelon fruit in response to grafting on interspecific cucurbit rootstocks. J. Food Qual. 2015, 38, 21-29. [CrossRef]

20. Food and Agriculture Organization of the United Nations. FAOSTAT2013; FAO: Rome, Italy, 2010; Available online: http://faostat3.fao.org (accessed on 27 July 2020).

21. Kyriacou, M.C.; Rouphael, Y.; Colla, G.; Zrenner, R.; Schwarz, D. Vegetable grafting: The implications of a growing agronomic imperative for vegetable fruit quality and nutritive value. Front. Plant Sci. 2017, 8, 741. [CrossRef]

22. Corey, K.A.; Schlimme, D.V. Relationship of rind gloss and grounds pot colour to flesh quality of watermelon fruits during maturation. Sci. Hortic. 1988, 34, 211-218. [CrossRef]

23. Huitron, M.V.; Ricárdez, M.; Dianez, F.; Camacho, F. Influence of grafted watermelon plant density on yield and quality in soil infested with melon necrotic spot virus. HortScience 2009, 44, 1838-1841. [CrossRef]

24. Bruton, B.D.; Fish, W.W.; Roberts, W.; Popham, T.W. The influence of rootstock selection on fruit quality attributes of watermelon. Open Food Sci. J. 2009, 3, 15-34. [CrossRef]

25. Cushman, K.E.; Huan, J. Performance of four triploid watermelon cultivars grafted onto five rootstock genotypes: Yield and fruit quality under commercial growing conditions. Acta Hortic. 2008, 82, 335-337. [CrossRef]

26. Davis, A.R.; Perkins-Veazie, P. Rootstock effects on plant vigor and watermelon fruit quality. Cucurbit Genet. Coop. Rep. 2005, 28-29, 39-42. 
27. Özdemir, A.; Çandır, E.; Yetişir, H.; Aras, V.; Arslan, Ö.; Baltaer, Ö. Effects of rootstocks on storage and shelf life of grafted watermelons. J. Appl. Bot. Food Qual. 2016, 9, 191-201. [CrossRef]

28. Soteriou, G.A.; Siomos, A.S.; Gerasopoulos, D.; Rouphael, Y.; Georgiadou, S.; Kyriacou, M.C. Biochemical and histological contributions to textural changes in watermelon fruit modulated by grafting. Food Chem. 2017, 237, 133-140. [CrossRef]

29. Leskovar, D.I.; Bang, H.; Kolenda, K.; Perkins, P.; Franco, J.A. Deficit irrigation influences yield and lycopene content of diploid and triploid watermelon. Acta Hortic. 2004, 628, 147-151. [CrossRef]

30. Bangalore, D.V.; McGlynn, W.G.; Scott, D.D. Effects of fruit maturity on watermelon ultrastructure and intracellular lycopene distribution. J. Food Sci. 2008, 73, S222-S228. [CrossRef]

31. Tadmor, Y.; King, S.; Levi, A.; Davis, A.; Meir, A.; Wasserman, B.; Hirschberg, J.; Lewinsohn, E. Comparative fruit colouration in watermelon and tomato. Food Res. Int. 2005, 38, 837-841. [CrossRef]

32. Perkins-Veazie, P.; Collins, J.K.; Davis, A.R.; Roberts, W. Carotenoid content of 50 watermelon cultivars. J. Agric. Food Chem. 2006, 54, 2593-2597. [CrossRef] [PubMed]

33. Perkins-Veazie, P.; Collins, J.K.; Pair, S.; Roberts, W. December. Watermelon: Lycopene content changes with ripeness stage, germplasm, and storage. Cucurbitaceae 2002, 3, 427-430.

34. Kyriacou, M.C.; Leskovar, D.I.; Colla, G.; Rouphael, Y. Watermelon and melon fruit quality: The genotypic and agro-environmental factors implicated. Sci. Hort. 2018, 234, 393-408. [CrossRef]

35. Perkins-Veazie, P. Ripening events in seeded watermelons. HortScience 2007, 42, 927.

36. Proietti, S.; Rouphael, Y.; Colla, G.; Cardarelli, M.; De Agazio, M.; Zacchini, M.; Moscatello, S.; Battistelli, A. Fruit quality of mini-watermelon as affected by grafting and irrigation regimes. J. Sci. Food Agric. 2008, 88, 1107-1114. [CrossRef]

37. Çandir, E.; Yetişir, H.; Karaca, F.; Üstün, D. Phytochemical characteristics of grafted watermelon on different bottle gourds (Lagenaria siceraria) collected from the Mediterranean region of Turkey. Turk. J. Agric. For. 2013, 37, 443-456. [CrossRef]

38. Schofield, A.; Vasantha Rupasinghe, H.P.; Gopinadhan, P. Isoprenoid Biosynthesis in fruits and vegetables. In Postharvest Biology and Technology of Fruits, Vegetables and Flowers; Paliyath, G., Murr, D.P., Handa, A.K., Lurie, S., Eds.; Wiley-Blackwell Publishing: Ames, IA, USA, 2008.

39. Tarazona-Díaz, M.P.; Viegas, J.; Moldao-Martinsc, M.; Aguayoa, E. Bioactive compounds from flesh and by-product of fresh-cut watermelon cultivars. J. Sci. Food Agric. 2011, 91, 805-812. [CrossRef]

40. Kader, A.A. Flavor quality of fruits and vegetables-Perspective. J. Sci. Food Agric. 2008, 88, 1863-1868. [CrossRef]

41. Magwaza, L.S.; Opara, U.L. Analytical methods for determination of sugars and sweetness of horticultural products-A review. Sci. Hortic. 2015, 184, 179-192. [CrossRef]

42. Maynard, D.N.; Dunlap, A.M.; Sidoti, B.J. Sweetness in diploid and triploid watermelon fruit. Cucurbit Genet. Coop. Rep. 2002, 25, 32-35.

43. Alan, O.; Ozdemir, N.; Gunen, Y. Effect of grafting on watermelon plant growth, yield and quality. J. Agron. 2007, 6, 362-365. [CrossRef]

(C) 2020 by the authors. Licensee MDPI, Basel, Switzerland. This article is an open access article distributed under the terms and conditions of the Creative Commons Attribution (CC BY) license (http://creativecommons.org/licenses/by/4.0/). 